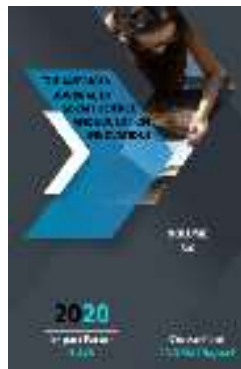

Journal Website: http://usajournalshub.c om/index,php/tajssei

Copyright: Original content from this work may be used under the terms of the creative commons attributes 4.0 licence.

\section{Preliminary Reviews Of The Late Medieval Historical Geography Of Jizzakh (On The Basis Of Written Sources And Archaeological Data)}

\section{Pardaev Ahrorqul Hasanovich}

Associate Professor Of The Department Of History And Teaching Methods Candidate Of Historical Science Jizzakh State Pedagogical Institute, Uzbekistan

Turabek Hasanboev

Doctoral student, Jizzakh State Pedagogical Institute, Uzbekistan

\title{
ABSTRACT
}

The article examines the historical medieval towns, fortresses and other geographical areas of the Jizzakh oasis based on written sources and data obtained from archeological excavations. As a result of scientific analysis, the geographical locations of the Jizzakh Horde and its environs, which are the location of the modern city of Jizzakh in the late Middle Ages, have been clarified.

\section{KEYWORDS}

Jizzakh Horde, Ustrushona, Sangzor river, Kaliyatepa city monument, Khaliliya village, Uchtepa district, Tupurkurgan, “Khoja Gaziyon” cemetery, “Jilovdor ota” cemetery, Ilonutti gorge, Yoyilma village, Kukrabot.

\section{INTRODUCTION}

Located in the central part of Movarounnahr, bordering on ancient cultural oases such as Sogd, Shosh, Davan (Fergana), the ancient and medieval Ustrushana has long been recognized as a country with a number of natural and geographical advantages. A number of scientific studies have been conducted on the political, socio-economic history, archeology, material culture and historiography of Ustrushana in ancient and medieval times. 
It should be noted that the historical geography of the oasis is no exception to such research, especially V.V. Barthold's classic scientific work "Turkestan in the epoch of the Mongolian people" gives a wide range of historical geography of Ustrushan (including Jizzakh) as in other regions [4.Bartold B.B.] N.Negmatov's "Historical- geographical essay Ustushany s drevneyshix vremen po Xv.n.e." His large-scale scientific article is devoted to the history and geography of the region, and the study introduced a number of innovations and clarifications to this problem [15. Negmatov H.H.]

\section{THE MAIN RESULTS AND FINDINGS}

Later, a number of scientific works on the historical geography, archeological and topography of the studied cultural region were published. [14. Mukhtorov A.], [2. Berdimurodov A.E.].

It should be noted that almost all of the above studies (except for the works of A. Mukhtorov) are devoted to the material culture of the ancient and medieval period before the invasion of Genghis Khan, in part, to the historical geography. It is known that in the period after the Mongol-Tatar invasion led by Genghis Khan, great changes took place in the historical geography not only of Ustrushana, but also of the whole of Movaraunnahr and all the conquered lands. For example, the cities and towns plundered by the Mongols after a while were mostly erected in other areas, and therefore their previous historical names changed. In some cases, the established cities did not reach their previous economic, administrative and cultural levels, and therefore they no longer functioned as cities, but as villages, settlements or settlements. [7. Pardaev A.] These conditions and reasons research on the history and geography of the late Middle Ages makes it clear that it is a topical issue that clarifies and clarifies many historical realities at the present time.

Among the researches on the history and geography of the Central Asian khanates of Ustrushana, the scientific works of A. Mukhtorov are noteworthy. However, in his scientific research, the author focuses more on the historical and geographical issues of Uratepa and surrounding areas, central Ustrushana [14.Mukhtorov A.]. The northern and north-western regions of Ustrushana, and the present-day Syrdarya and Jizzakh oases, are excluded from the scope of such studies. Therefore, this article provides an overview of the late medieval history and geography of Jizzakh on the basis of available written sources and archeological data, as well as scientific information on the ancient administrative division (rustoq), the principality and its central city. [20. Pardaev A.H.]

Jizzakh city. There are archeological and written sources proving the antiquity of the city. Jizzakh was first found in the form of "Dizak" in the works of medieval historians and geographers, and a descriptive description of the city is given [3. Betger E.K.].

The geographical location of Jizzakh really has a number of advantages. In particular, the source of running water (Sangzor), arable lands (Sangzor valley), pastures, mountains and desert areas are clear examples of this. The fact that Jizzakh is located at the "intersection" of the Great Silk Road, which connects the countries and cities of Central Asia and the neighboring region economically, has also left an important positive mark on its economic and cultural life. The place of Jizzakh in the 
ancient and developed Middle Ages is recognized by experts as the site of Kaliyatepa, located in the eastern part of the city of Jizzakh [2.Berdimurodov A.E.]. From the time of Amir Temur, Qaliyatepa began to function not as the capital of the oasis, but as one of the main military strongholds. The reason for this reasoning is that only in the Shahristan and Ark part of Qaliyatepa there are later medieval cultural strata, in the rabods around it life did not continue during this period. [22.Pardaev M.H.] The total area of Qaliyatepa Shahristan and Ark is 5 ha. Given that the area is around, this area is quite small for a city like Jizzakh (Dizak), which played an important militarystrategic role in the last Middle Ages [17.Pardaev A.H]. This means that in the time of Amir Temur, the life of the central city was $6 \mathrm{~km}$ from Qaliyatepa. moved to the Horde in the northwest. At the beginning of the XVII century, life in Qaliyatepa completely stopped [19.Pardaev A.H]. In this regard, the "Boburnoma" also contains the following information. The author of the work describes his arrival in Jizzakh as follows ... "We arrived in the village of Khaliliya before dawn. Dizak came from Khaliliya "... [5. Bobur Z.M].

Experts have not yet commented on the location of the town of Khaliliya. In our opinion, it is not unlikely that the village of Khaliliya was located on the site of Qaliya (hill)33. In addition, there was a village (now a makhalla (neighbourhood)) called "Kaliya-Molkanlik". So, Babur Mirza with his small number of servants first went to the roadside village of Khaliliya (Qaliya) and then to Dizak (Orda), which is located inside the oasis. The term Khaliliya may be related to the name of the Timurid prince Khalil Sultan. Because, first of all, it was customary to call cities and towns after princes during this period. Second, Khalil
Sultan ruled in Movarounnahr for some time (1405-1409), although he did not follow the will of the Sahibkiran. Thirdly, in the Kazan edition of "Boburnoma" the village of Khaliliya was named as the village of Ulug Khalil [5. Bobur Z.M].

There is no doubt that the place of the city of Dizak in the time of the Shaybanids was in the place of the present Horde. In the chapter of "Abdullanoma" on the events of June 1579, Abdullah Khan, who was returning from Tashkent to Samarkand in a hurry,first arrived to Uchtepa and thensent a person from there to Dizzakh to Ali Mardon Bahadir , on that day during the noon prayer (enemy) from the burning place of Hakan (Uchtepa-P.A) moved and planted a flag of residence in a district called Dizzakh "[6. Hafiz Tanish al-Bukhari]). By the way, the reason for Abdullah's speedy return to Samarkand was the fact that his rival Sultan Bozakhor and his brothers conquered Samarkand and killed Amir Minglibi, a khan appointed by the khan. According to the source, Uchtepa is $10 \mathrm{~km}$ from Jizzakh (namely Urda) that is a village on the north-east side. The surrounding area of the village is also called Uchtepa desert, Uchtepa district. The term Uchtepa district first appears in 16th century sources. This area existed in the XIX century and was the sixth address on the Samarkand-Tashkent road. The shortest way through Uchtepa was to go directly to Dordakh-Qaliyatepa, not to Urda.

The distance between Uchtepa and Qaliyatepa is almost $17-18 \mathrm{~km}$. Qaliyatepa is located on the south-east side relative to Uchtepa. Assuming that Dizzakh was in the place of Qaliyatepa, Abdullah Khan, who was in a hurry to Samarkand for the reason given above, returned a certain distance and, without any 
necessity, extended the army's route by almost $3 \mathrm{~km}$. On top of that, Kukrabot, which is close to Qaliyatepa, on the border of the desert district, stopped at Uchtepa, which is much farther from Qaliyatepa, without stopping at Yoyilma districts (we will discuss these areas below). So, logically, this period was the place of the present-day Horde, located in the area of the "Old City" in the northern part of the city of Dizzakh-Jizzakh, mentioned in written sources. By the way, this place, which is called "Tupurkurgan" and "Urda" by the locals, served as the administrative center and capital of the Jizzakh principality of the Bukhara Emirate during the khanate. [23.Pardaev A.H]. According to recent data, the Horde is surrounded by three rows of defensive walls, with a total area of at least 100 hectares. It has three gates, the north-east of which is called the Tashkent Gate, the south-east is called the Uratepa Gate, and the south-west is called the Samarkand Gate [12.Maev H.], [17. Pardaev M.H., Pardaev A.H].

According to ethnographic data, the residents of Jizzakh lived from late autumn to spring in the neighbourhood (makhallas) within the Tuprakkurgan (Urda), in the kurgan yard, and during the sowing season in the field yard in the farming area. According to 96-year-old Shahri Mother Artikova and 90-year-old Munavvarhoji Tursunov, "the courtyards in the fortress were so dense that it was possible to walk around the whole Horde."

Although the main part of the population of Jizzakh was located within the Horde, they also had lands engaged in agriculture and horticulture in the areas around the fortress. The area around the various agricultural crops, gardens and meadows in these areas is often surrounded by cotton walls. The craftsmen's workshops and rastas were outside the Horde's defensive wall. According to the information, in order to better see and control the military action of the Russian invading forces that attacked the Jizzakh Horde in October 1866 , by the order of the Horde prince Olloyor, the market stalls around Tuprakkurgan were demolished and trees were cut down [8.Haydarov $\mathrm{H}$ ].

The water supply of the Horde was undoubtedly provided by the Jizzakhlik canal, which flowed from its south to the east-west of the Sangzor.

It should be noted that at present in the territory of Jizzakh almost no historical and architectural monuments of the late Middle Ages are preserved, and little is known about their historical names and locations.

According to sources, on the southwest side of the Horde, around the present-day Nuriddin Haji Madrasa, was the Namazgoh (lydgoh) mosque. Twice a year, on the days of Ramadan and Eid al-Adha, prayers were held here, and the area around the mosque was surrounded by four cotton walls, with only a terrace on the qibla side. Around the Samarkand Gate is the "Artillery", where it is said that the cannons were stored and repaired [23. Pardaev A.H.].

Another surviving historical place name is the term "Park". The park is $1.2 \mathrm{~km}$ from Urda. The distance is on the south side, in a flat, flat place. Every neighborhood moved here and planted grass, plov, halim, sumalak were cooked on the stoves, wrestling, kupkari competitions were held, singers, amateurs, drummers and puppet shows performed.

Outside the Gate of Uratepa there was a place called Kalandarkhona, and the name has survived to this day. This place is known as a 
place of rest for dervishes and kalandars from Jizzakh and other cities, a place of worship, recitation and remembrance. Not far from Kalandarkhana, on its north-western side, was a place called Takyakhona.

In ancient and medieval times, the main water source not only in the city of Jizzakh, but also in the whole oasis was the Sangzor River. The water used for drinking and irrigated agriculture in the city and district of Jizzakh, due to the nature of the riverbed, required a single, decentralized location. At least $2.2 \mathrm{~km}$ from Urda. In the distance there is a historical place called "Five Pipes" in the south. Here, the water of the Sangzor River is distributed through twelve canals to the agricultural supply of Jizzakh makhallas through a five-pipe water separation facility. All twelve canals are named after Jizzakh makhallas [24. Pardaev A.H., Muminova G.I., Pardaev J.A].

According to the information at our disposal, there are three old (still in operation) cemeteries directly connected with the ancient and medieval city of Jizzakh. The first of them is "Jilovdor ota" cemetery, located on the west side of Qaliyatepa. The total area of "Jilovdor ota" is 4 hectares. around, he also took possession of part of the 4th rabod of Qaliyatepa, where life ceased in the eighth century. This cemetery functioned for Qaliyatepa and the surrounding villages.

About $1 \mathrm{~km}$ from Urda in the distance, on its north-eastern side, is the Khoja Gaziyon cemetery. The total area of Khoja Gaziyon is 10 hectares.

According to medieval authors, the city of Jizzakh was famous in the IX-X centuries as the main stronghold of the "Islamic army - the Gazis", defending the Ustrushan and Sogdian lands, which converted to Islam from the looting of nomadic peoples. The basis of the "Gazis" was formed by the descendants of the daughter of Muhammad, Fatima, and the sonin-law of the Caliph Ali, "masters" [18.Pardaev A.H]. The purpose of this statement is that the Khoja Ghazian cemetery began its activities at least in the IX-X centuries and is directly related to the activities of the Ghazi in Jizzakh. A number of ancient tombstones have been preserved in the Khoja Gaziyon cemetery. If these tombstones are read and studied to determine the identity of the corpses and their periodic dates, important changes can be made in the history of the city of Jizzakh.

The third ancient cemetery is called "Khojamozor", 850-900 m from the Horde located in the southeast. Its total area is 3.5 hectares. According to the elders, "Khojamozor" was originally a dynastic cemetery of mainly aristocrats, great scholars and officials. Later, residents of (makhallas) neighbourhood in the eastern and southeastern part of Jizzakh began to use it.

The above ideas about the historical geography of the city of Jizzakh were formed at the same time through the historical, archaeological, ethnographic data at our disposal. According to V.L Vyatkin, who studied the history and geography of Samarkand on the basis of foundation documents, the location of markets, location and direction of the streets were almost the same as in the Shaybanids in the 6os of the XIX century, on the eve of the Russian invasion [9. Vyatkin V.L]. In order to draw such final conclusions on the history and geography of the city of Jizzakh, we still have the resources and information.

Jizzakh district (principality). It is not clear when the Jizzakh principality was formed. It is 
not unlikely that this happened in the traditional way. This is because in the Middle Ages, the north-western rustak (province) of Ustrushana, Fagnan, and its central city, Dizak, were territorially located on the site of the present-day city and district of Jizzakh [16.Pardaev A.H]. The seventeenth-century geographer Mahmud ibn Vali in his work states that in ancient times Khojand, Uratepa, Dizzakh and other eastern regions were under the rule of Samarkand, and lists Jizzakh as a separate region [13. Mahmud ibn Vali].

We also do not have exact information about the territory and borders of the Jizzakh principality. In any case, there is no doubt that this administrative territory was in the middle reaches of the Sangzor River. The total area of the principality is about $25-30 \mathrm{~km}$ in diameter. Thus, in the late Middle Ages, the borders of the Jizzakh principality were bordered on the south by the village of Ravot, Uvob gorge, Karatag and Morguzar mountains, on the west and southwest by the llonutti gorge, on the north and east by Mirzachul. We start with the available information on the historical and geographical location of the principality in the south-west of the llonutti gorge.

In ancient and medieval times, llonutti gorge was a place of great strategic importance for Jazzakh and Samarkand. In the chapter of "Zafarnoma" about the owner's "attention to China" it is reported that he passed through Ilonutti [10. Sharafuddin Ali Yazdiy]. Mirza Babur also writes in his memoirs that he stopped in this area and called him Ilonotti. Hafiz Tanish al-Bukhari also narrates in his work that "Abdullah Khan fought and defeated Navruz Ahmad Khan's sons and grandsons twice a day at Ilonutti."
According to the author, the battle took place in the desert at the exit of Dara to Samarkand [6. Hafiz Tanish Bukhari].

So, llonutti is a narrow gorge between Nurata and Morguzar mountains, the only road connecting the Zarafshan oasis with Ustrushana, Chach-Ilak, Fergana. The eastern part of Dara is $13 \mathrm{~km}$ from Jizzakh, located in the southwest. The total length of the Ilonutti is $12 \mathrm{~km}$.

Written sources also mention an area called Kokgumbaz near Ilonutti. In particular, "Abdullanoma" contains information about the khan's army, which set out from Samarkand and passed through the area of Khuddin (Gubdin -P.A.). However, the commentary in the book states that the Blue Dome is located on the south side of Samarkand, on the road to Bukhara [6. Hafiz Tanish Bukhari]. In fact, the exit of the Kokgumbaz Ilonotti gorge on the Samarkand side was nearby. There is now a village called Kokgumbaz on the left bank of the Sangzor River. According to M. Pardaev, on the steep bank of the river, on a high hill, there is an archeological monument called Kokgumbaz. Although no excavations have been carried out in Kokgumbaztepa due to its conversion to a cemetery, pottery from the 14th-16th centuries found on and around it allows us to determine the most recent periodic date of life in it. Legend has it that the Kokgumbaz fortress was built by the efforts of Bibi Khanum, the beloved wife of Amir Temur.

The southern and southeastern borders of the principality area under study are bounded by the Volga gorge mentioned in the sources. In "Abdullanoma" there is information that the khan's armies ... "crossed the unusual Vol valley and went to Zaamin". The location of the Vol 
gorge is not specified in the book and is assumed to be the gorge road from Jizzakh to Zaamin [6. Hafiz Tanish Bukhari]. It is known that on the road from Jizzakh to Zaamin there are no mountains, and there is no mountain gorge. According to the source, the army was on an "unusual" route, bypassing Jizzakh and heading for Zaamin. The Volga Gorge is a mountain road about $20 \mathrm{~km}$ long that passes through the present-day villages of Korpa and Parpiota.

The distance of this road from Samarkand to Jizzakh is almost twice as short as the road through Jizzakh, which started from the present-day village of Avliyo when it came from Samarkand and started from the village of Ravot. In this area there is the village of Uvob, a spring of water called Uvobsoy, probably a later variant of the name Vol.

This source gives information about another mountain road, Ardahshan gorge, such as "the guards of the steppe army came forward to catch the "tongue" and settled in the Ardahshan gorge" [6. Hafiz Tanish Bukhari].

The Ardakhshan gorge (now there is a village of the same name here) runs parallel to it on the south side of the Jizzakh-llonutti road. The starting point of the Dara on the Samarkand side was near the present-day village of Zargar, the Blue Dome. By the way, on his way back from this military trip, Abdullah passed through Ardahshan and stopped at the Blue Dome.

Another area frequently mentioned in late medieval sources is the Rabot Fortress. Surprisingly, in the sources this address is mentioned as "Raboti Malik", in some cases it is also called "Malik". In particular, in "Zafarnoma" - "Hirman was sitting in Dizak with a thousand people ... Jahanshohbek came to Rabati Malik with one thousand five hundred people and killed him ... he went to Malik sori with two hundred people ... Malik's companion could not stand They fled together "[10. Sharafuddin Ali Yazdiy]. It is known from the description of the events that the army of Amir Temur clashed with the army of Amir Hussein around Jizzakh and won. However, the commentary on this historical work states that Raboti Malik was built by the Karakhanid khan Shamsulmulk in 1078-79 near the village of Harjang in the Karmana desert [10. Sharafuddin Ali Yazdiy].

The following lines are contained in the chapter of Hafiz Tanish Bukhari's work "Hazrat Sahibkiran's turn to the Zaamin region for the purpose of war with Babasultan". "The heroes of the two sides met at a place called Raboti Malik. A great battle broke out and a fierce war broke out" [6. Hafiz Tanish Bukhari]. So, it is self-evident that in addition to Raboti Malik (now Malik Rabot) in the Karmana Desert, another rabot with the same name existed in the Jizzakh oasis. As it turned out, Raboti Malik is $24 \mathrm{~km}$ from Jizzakh. It was in the area of the present-day village of Ravot, southeast. Indeed, according to archeological data, $400 \mathrm{~m}$ from each other on the south side of the village of Ravot. In the distance, the ancient fortresses Turtkultepa, Nameless Hill have been preserved, and their last construction period dates back to the XVI-XVII centuries [21. Pardaev A.H]. Raboti Malik was located in the place of one of the remains of this fort.

There is enough information in the modern literature about Ogachti raboti (sardobasi) located in the desert area on the north-eastern side of Jizzakh. It is acknowledged in the literature that the building was built by Abdullah. [11. Bilalov A.I] Rabot in 
"Abdullanoma" it is called Wooden raboti, but no information about its creator is given. In fact, next to the rabot was a wooden cistern that has survived to the present day. The sardoba provided drinking water to the caravans and armies passing through Mirzachul. According to archeological data, the rabot mentioned in the source is located on the south side of the sardoba and dates back to the 15th century [11. Bilalov A.I], [9. Suyunov C.C).

The next districts mentioned in "Abdullanoma" are Kokrabot and Yoyilma. In the source, these areas are mentioned in the narration of the great khan's story "Passing through Kokrabot and falling into the Spread" [7.Hafiz Tanish Bukhari]. Both districts are located in the eastern part of Jizzakh, about $15 \mathrm{~km}$ from each other. The book's commentary states that the location of both addresses could not be determined. Kokrabot is a sacred place called Kokrabot in the Kurgantepa district of the present-day Sh. Rashidov district. In the Middle Ages there was a Khudaysar rabati built here by the Ustrushona afshin. Khudaysar is one of the most famous rabbis of Movarounnahr. It has a mosque, waqf lands, a water source, drinking water is taken from a well, and running water is taken from Sangzor through the Uruqilisay, where the river is still preserved. No late medieval material has been recorded in this area during archeological research (18. Pardaev $\mathrm{M} . \mathrm{H}]$. Hence, in this period, i.e. in the 16th century, the term Kokrabot was used only as a place name.

There are two places in the oasis now called Yayilma. The first is Yoyilma village of N.Abduolimov company of Jizzakh district, the second is $5 \mathrm{~km}$ from Katta Uzbek tract steppe area on the east side. The second place, called the spread, corresponds to the area mentioned in the source. According to archeologistscientist M.Pardaev, during the search for archeological monuments in the Jizzakh oasis in the 1980s, the ruins of the village, the place of the old cemetery, XV-XVI; Samples of pottery from the XVII-XIX centuries were collected. Indeed, according to local elders, this was the first historical village of Yoyilma, and in the 1920 s the village moved to its present location. According to S. Anarbaev, who conducted research on the history of irrigation of the oasis in the late Middle Ages, the waters of Ravotsay in ancient times flowed to Yoyilma [1. Anorboev C].

\section{CONCLUSION}

Thus, it can be concluded that a comparative study of the available archeological data with the most authoritative and reliable written sources of the late Middle Ages made the first comments on the historical-geography of the city of Jizzakh and its environs. Obviously, there are areas in the opinions expressed that need to be discussed. However, it should not be forgotten that this work is a prelude to future research on the late medieval history and geography of Jizzakh and Syrdarya regions, the first experience of research in this area.

\section{REFERENCES}

1. Anorboev S. Iz istorii orosheniya Djizakskogo oasis (1917-1967 gg.). Autoref. diss. kand. ist. science. Tashkent, 1971.

2. Berdimuradov A.E.Rannesrednevekovye archeological monuments of Djizak oasis (Severo-Zapadnoy Ustrushany $\mathrm{V}-\mathrm{X} \mathrm{Vv}$.). Autoref. dis.kand.ist.nauk. - M., 1985, - 23 p. 
3. Betger E.K. Excerpts from the book "Puti $i$ strany" Abul-Kasima ibn Xaukalya // Trudy SAGU. Archeology Sredney Azii. Vyp. IV, T „1957, p. 17-22.

4. Bartold V.V, Turkestan $\mathrm{v}$ epoch mongolskogo nashestviya // Soch., T, 1. M., 1963, p. 253-255.

5. Zahiriddin Muhammad Bobur. Boburnoma. Tashkent, 1989, 368 p.

6. Hafiz Tanish al-Bukhari, Abdullanoma ("Sharafnomai shahiy"\}. The first book. Tashkent, 1999, 414 p.

7. Pardaev A.H. From the history of ethnic neighborhoods of Jizzakh (Jizzakh oasis in the system of (entral Asian civilization) (from ancient times to the present). Republican scientific-practical conference. Jizzakh, 2020, pages 243-248.

8. Haydarov H. History of Jizzakh region, Tashkent, 1996, 320 p.

9. Vyatkin V.L, Materials on the historical geography of Samarkand region. Samarkand, 1902, - 83 p.

10. Sharafuddin Ali Yazdiy. "Zafarnoma". Tashkent, 1997, 382 p.

11. Bilalov A.I. From the history of irrigation Ustrushany, // Dushanbe, 1980, $192 \mathrm{~s}$

12. Maev N. Djizak and Samarkand.// Turkestanskie vedomosti. May 21, 1870 № 2.

13. Mahmud ibn Wali. More tayn otnositelno doblestney blagorodnyx (geography). Tashkent, 1977, 166 p.

14. Mukhtarov A. History Ura-tyube (end XVnachalo XX. Vv.). M., 1998, 278 p.

15. Negmatov N.N. Historical-geographical essay Ustrushany $s$ drevneyshix vremen po X v. n.e. // MIA, № 37, M.-L., 1953, - p. 231-252.

16. Pardaev AH, Orda - the administrative and economic center of the Jizzakh oasis.
News of the National University of Uzbekistan. Tashkent, 2014, 17-21 p.

17. Pardaev M.X., Pardaev A.X. Djizakskiy oasis in the epoch of the late Middle Ages // Archeology. numismatics and epigraphy srednevekovoy Sredney Azii. Samarkand, 2000, 121-132 p.

18. Pardaev M. $\mathrm{K}$ archeologicheskomu izucheniyu Djizakskogo oasis // Arxeologiya Sredney Azii. TD, Tashkent, 1990, - 78-79 p.

19. Pardaev A. Some comments on the history of Samarkand and Jizzakh mahallas // Conference on "Zarafshan oasis and its place in history." Materials Part 1, Samarkand, 2001, 145 p.

20. Pardaev A.H. In the written sources of XVXVI centuries Jizzakh.// UMMT, issue 32, Tashkent, 2001. 251-255 p.

21. Pardaev A.H. Ilonotti Gorge - Some comments on the formation and historical significance of the Iron Gate. - (Ancient Jizzakh oasis - in the system of Central Asian civilization (political, economic, cultural life)) Proceedings of the Republican scientific-practical conference. Tashkent, 2019, 75-80 p.

22. Pardaev M.H. Some comments on the monument of Qaliyatepa city and its stratigraphy // UMMT No. 31, Samarkand, 2000, pp. 119-130.

23. Pardaev A.H. Urbanization processes in the Jizzakh oasis during the Central Asian khanates. International Scientific Journal Theoretical \& Applied Science. Published: 30.11.2019 http://T-Science.org

24. Pardaev A.H., Muminova G.I., Pardaev J.A. Some Comments on the Social Status of the Uzbek Family in the End of the XIX Century - The First Half of the XX Century. International Journal of Psychosocial 
Rehabilitation. Vol. 24, Issue 04, 2020.

ISSN: 1475-7192, 7108-7115 pgs.

25. Хайназаров, ь. Б. (2017). ИЗ ИСТОРИИ

ФОРМИРОВАНИЯ УЙГУРСКОЙ

ДИАСПОРЫ В УЗБЕКИСТАНЕ. Theoretical \& Applied Science, (3), 51-55.

26. Хайназаров, Б. (2013). Из истории уйгуров Республики Узбекистан. Научное обозрение: теория и практика., (1), 57.

27. Mirkomil, G., \& Matluba, G. (2020). WAYS TO DEVELOP MODERN ECOTOURISM IN THE ZAAMIN BASIN. International Engineering Journal For Research \& Development, 5(7), 5-5

28. Omonov, Q., \& Karimov, N. (2020). Importance Of Ancestoral Heritage. The American Journal of Social Science and Education Innovations, 2(09), 196-202.

29. Karimov, N. R. (2020). A True Successor of Great Central Asian Scholars. Journal «Bulletin Social-Economic and Humanitarian Research,(7), 62-69.

30. Djuraeva, S. (2020). THE ROLE OF SPIRITUAL AND MATERIAL HERITAGE OF SURKHANDARYA REGION IN THE DEVELOPMENT OF TOURISM. Solid State Technology, 63(6), 290-296.

31. Kariev, A., \& Aminov, H. (2020). New information about Imam al-Zarnūjī and his work "Ta'līm al-Muta'allim". Solid State Technology, 63(6), 2372-2387. 